\title{
Effects of Prunella vulgaris labiatae extract on specific and non-specific immune responses in tilapia (Oreochromis niloticus)
}

\author{
Kwan-Ha Park and Sanghoon Choi
}

\begin{abstract}
We examined the effects of Prunella vulgaris Labiatae (P. vulgaris L.) on specific and non-specific immune responses of Nile tilapia, Oreochromis niloticus. The optimal concentration without toxicity of $P$. vulgaris was determined to $30-40 \mu \mathrm{g} / \mathrm{ml}$ in vitro and $120 \mu \mathrm{g} / 100 \mathrm{~g}$ of fish in vivo. P. vulgaris significantly elicited an antibody titer compared to FCA or $\beta$-glucan. $\beta$-glucan plus $P$. vulgaris group synergistically enhanced antibody production. No significant difference in antibody production was observed between $P$. vulgaris and $P$. vulgaris plus $\beta$-glucan group. A respiratory burst activity of head kidney (HK) leucocytes of tilapia administered with 300 or $500 \mu \mathrm{g} P$. vulgaris was significantly $(p<0.05)$ enhanced compared with the PBS-injected control group and FCA-treated group. Maximum increase in the NBT reduction value was observed in $500 \mu \mathrm{g} P$. vulgaris group but no significant difference was found between 300 and $500 \mu \mathrm{g}$. vulgaris group. The level of serum lysozyme activity was significantly $(p<0.05)$ higher in the 300 and $500 \mu \mathrm{g}$ P. vulgaris than $100 \mu \mathrm{g}$ P. vulgaris and FCA group. The phagocytic activities of HK leucocytes from tilapia administered with 300 and $500 \mu \mathrm{g}$ P. vulgaris were significantly $(\mathrm{p}<0.05)$ higher than $100 \mu \mathrm{g}$ $P$. vulgaris and the control group. $P$. vulgaris was revealed with a good immunoadjuvant evoking the specific and non-specific immune responses of tilapia.
\end{abstract}

Keywords: Prunella vulgaris, Respiratory burst activity, Lysozyme activity, Tilapia

\section{Background}

One of the most promising methods for controlling diseases in aquaculture is strengthening the defense mechanisms of fish through prophylactic administration of immunostimulants [1]. Immunostimulants are naturally occurring compounds that modulate the immune system by increasing host resistance to infectious pathogens, and they have been widely used in aquaculture [2-4]. Traditional disease control strategies employing antibiotics and chemical disinfectants are no longer recommended due to the emergence of bacterial resistance as well as concerns over the environment and wildlife protection. Although vaccination has been shown to be an effective prophylactic method for disease control in fish [5], there are some methodological problems related to high costs and stress [6]. Already, remarkable success has been achieved using

\footnotetext{
* Correspondence: shchoi@kunsan.ac.kr

Department of Aquatic Life Medicine, Kunsan National University, Gunsan, Geonbuk 573-400, South Korea
}

immunostimulants as a more environmentally friendly approach to disease management [7-9].

Several compounds, including $\beta$-glucans, chitin, algal and mistletoe extracts, and bacterial polysaccharides, have been used to enhance immunity and disease resistance in a variety of fish species [7,10-12]. $\beta$-glucan administration has been reported to augment antibody production, complement activity, lysozyme activity, phagocytic activity, and respiratory bursts in channel catfish Ictalurus punctatus [13], Atlantic salmon Salmo salar [14], rainbow trout Oncorhynchus mykiss [15], gilthead rainbow trout Sparus auratus [16], and sea bass Dicentrarchus labrax [17].

Prunella vulgaris is a perennial herb that is used in traditional medicine for the clinical treatment of sore throat, fever, and accelerated wound healing $[18,19]$. The organic fraction of $P$. vulgaris exhibits antioxidative and antimicrobial activities [18], whereas aqueous extracts of $P$. vulgaris inhibit HIV-1 infection [20]. In aquaculture, P. vulgaris was reported to have efficacy as a dietary supplement, although only up-regulation of natural immunity was observed [21]. 
To further study the availability of $P$. vulgaris as an immunoadjuvant to elicit a vaccination effect, we measured the specific antibody titer following intraperitoneal injection of $P$. vulgaris with an antigen in tilapia as a fish model.

To overcome the disease problem affecting fish culture systems, the present study applied indigenous $P$. vulgaris as an appropriate immnoadjuvant in order to augment specific and non-specific immunities as well as disease resistance in fish.

\section{Materials and methods}

\section{Fish}

Nile tilapia, Oreochromis niloticus, fish weighing about 100-150 g each were obtained from a fish farm in Kunsan National University, Korea and acclimated for 2 weeks to laboratory conditions in $70 \mathrm{~L}$ glass aquaria containing re-circulated and aerated water at $23-23^{\circ} \mathrm{C}$. They were acclimated to this environment for at least 2 weeks prior to use and fed daily using a commercial diet during the adaptation and experimental periods. The health status of the animals was checked daily by observing fish behavior, and there were no clinical symptoms such as abnormal swimming patterns or body color changes.

\section{Reagents}

Nitroblue tetrazolium (NBT), Percoll, hemocyanin (HC), 3-(4,5-dimethylthiazol-2yl)-2,5-diphenyl-2H-tetrazolium bromide (MTT), phorbol myristate acetate (PMA), and Minimum essential medium (MEM) were purchased from Sigma Chemicals CO. Hanks balanced salt solution (HBSS), fetal bovine serum (FBS), and antibiotic-antimycotic were obtained from Gibco BRL, Grand Island, NY. Sodium nitrite, sulfanylamide, and phosphoric acid were purchased from ICN Biomedicals. Bakers' yeast and Saccharomyces cerevisiae purchased from Oriental Yeast Co. Ltd., Tokyo, and thioglycollate broth was obtained from Difco Laboratories, Detroit, USA.

\section{Extraction of $P$. vulgaris}

$P$. vulgaris originating from South Korea was kindly donated by an herbal medicine company (Sanyacho-Nongwon, Namyangju, Korea). Extraction of $P$. vulgaris was performed according to Lee's method [22]. Briefly, the chopped flowers, stems, and leaves of P. vulgaris (100 g) were placed in distilled water $(1,000 \mathrm{ml})$ and stirred at $4^{\circ} \mathrm{C}$ overnight. After centrifugation at $15,000 \times g$ for $20 \mathrm{~min}$, the supernatant was filtered through $0.2 \mu \mathrm{m}$ pore-sized filters. Protein content of $P$. vulgaris extract was determined using a commercial protein assay kit (Bio-Rad Lab, USA) and stored at $4^{\circ} \mathrm{C}$.

\section{In vitro and in vivo toxicities of $P$. vulgaris}

The in vitro toxicity of $P$. vulgaris was tested against EPC and CHSE-214 fish cell lines. Respective cell lines $\left(1 \times 10^{6}\right.$ cells $)$ were dispensed into each well of a 24-well plate (Costar, USA), followed by administration of various concentrations of $P$. vulgaris extract ranging from $10 \mathrm{ng}$ to $100 \mu \mathrm{g} / \mathrm{ml}$. After incubation at $24^{\circ} \mathrm{C}$ for 3 days, MTT assay was performed according to the method of Daly et al. [23]. Briefly, the tissue culture plates were centrifuged at $500 \times$ $\mathrm{g}$ for $10 \mathrm{~min}$, after which the supernatant fluids were carefully removed without disturbing the cell pellet or formazan precipitate. The formazan crystals were then dissolved by addition of $200 \mu \mathrm{l}$ of dimethyl sulphoxide (DMSO) (Sigma) to each well, followed by $25 \mu \mathrm{l}$ of glycine buffer (0.1 M glycine, $0.1 \mathrm{M} \mathrm{NaCl}, \mathrm{pH} 10.5)$. Contents of the wells were then thoroughly mixed with a multichannel pipette. After $10 \mathrm{~min}$, formazan development was read at $595 \mathrm{~nm}$ using an ELISA reader (ASYS HITECH, Austria).

To determine whether or not $P$. vulgaris has serious toxicity in vivo, 100 and $1000 \mu \mathrm{g}$ of $P$. vulgaris/100 g of fish were intraperitoneally (I.P.) injected into seven fish per group. Fish blood was collected 4 days after injection, and the concentrations of glutamic oxaloacetatic trams aminase (GOT), glutamic pyruvate transaminase (GPT), and c-creatin were determined on a Fuji Dry Chem System (Fuji Photo Film Co. Ltd, Japan).

\section{Administration of $P$. vulgaris to elicit non-specific immune response in tilapia}

Tilapia were divided into five groups of seven fishes per group. Fish in each group were I.P injected with 100, 300 , and $500 \mu \mathrm{g}$ of $P$. vulgaris $/ 100 \mathrm{~g}$ of fish in $0.5 \mathrm{ml}$ of phosphate-buffered saline (PBS). The remaining group of fish was injected with an equivalent volume of sterile PBS or 1:1 emulsified Freund's complete adjuvant (FCA) (Sigma) as a control. On day 4 post-injection, blood and head kidney leucocytes were obtained from each fish.

\section{Antibody production upon administration of $P$. vulgaris plus other immunostimulants}

The immunostimulating effect of $P$. vulgaris was compared with those of FCA and $\beta$-glucan based on elevated antibody production. $\mathrm{HC}$ was used as an antigen to evoke a specific antibody response. For I.P. injection, $300 \mu \mathrm{g}$ of P. vulgaris and $100 \mu \mathrm{g}$ of $\mathrm{HC}$ were mixed and administered in a volume of $200 \mu$ l. Tilapia were divided into six groups (five fish per group), after which $\mathrm{HC}$ was injected alone (control) or mixed and injected with $100 \mu \mathrm{l}$ of other adjuvants. The total injection volume was adjusted to $200 \mu \mathrm{l}$ in all experiments. P. vulgaris was I.P. injected at a concentration of $300 \mu \mathrm{g}$ suspended in $200 \mu \mathrm{l}$ of phosphate-buffered saline (PBS). In the FCA group, $100 \mu \mathrm{l}$ of FCA was 1:1 emulsified with HC suspended in $100 \mu \mathrm{l}$ of PBS. In the FCA plus $P$. vulgaris group, $100 \mu \mathrm{l}$ of FCA was added to the $P$. vulgaris and HC mixture and then I.P. injected at a volume of $200 \mu \mathrm{l}$. The optimized concentration $(50 \mu \mathrm{g})$ of $\beta$-glucan was injected with $\mathrm{HC}$ at a volume 
of $200 \mu \mathrm{l}$. In the $\beta$-glucan plus $P$. vulgaris group, $50 \mu \mathrm{g}$ of $\beta$-glucan and $300 \mu \mathrm{g} P$. vulgaris were mixed together and I.P. injected at a volume of $200 \mu \mathrm{l}$. On day 30 postinjection, blood was harvested from the fishes in each group, followed by antibody titer assay using an ELISA reader.

\section{Isolation of head kidney (HK) leucocytes}

The method described by Santarem et al. [24] was followed with some modifications. The tilapia HK was dissected out by ventral incision, cut into small fragments, and then transferred into $5 \mathrm{ml}$ of HBSS. Cell suspensions of the HK were obtained by teasing HK tissues with two slide glasses in HBSS in a Petri dish (Coring, USA). After sedimentation of tissue debris at $4^{\circ} \mathrm{C}$ for 1 min, the supernatants were removed. HK cell suspensions were then layered over a 34-51\% Percoll gradient and centrifuged at $1000 \times \mathrm{g}$ for $40 \mathrm{~min}$ at $14^{\circ} \mathrm{C}$. After centrifugation, leucocyte bands located above the 34$51 \%$ interfaces were collected using a Pasteur pipette and washed twice at $120 \times \mathrm{g}$ for $8 \mathrm{~min}$ in HBSS. The concentration of viable cells was determined by trypan blue exclusion.

\section{Serum}

Blood was collected from the dorsal aorta of tilapia. Blood was allowed to clot at $20^{\circ} \mathrm{C}$ for $30 \mathrm{~min}$ and then cooled at $0^{\circ} \mathrm{C}$ for $1 \mathrm{~h}$. Serum was obtained by centrifugation at $1000 \times \mathrm{g}$ for $8 \mathrm{~min}$. Sera were frozen at $-20^{\circ} \mathrm{C}$ until used.

\section{Reactive oxygen intermediates (ROI) production assay}

ROI production by tilapia kidney cells after administration of $P$. vulgaris was assessed by monitoring reduction of NBT [25]. Leucocytes $\left(1 \times 10^{5}\right.$ cells $)$ were washed once with $\mathrm{HBSS}$ at $60 \times \mathrm{g}$ for $3 \mathrm{~min}$ at $4^{\circ} \mathrm{C}$ and then incubated in $100 \mu \mathrm{l}$ of complete media in the presence of PMA and $1 \mu \mathrm{g} / \mathrm{ml}$ of NBT. After $1 \mathrm{~h}$ of incubation at $25^{\circ} \mathrm{C}$, excess $\mathrm{NBT}$ was washed out with $\mathrm{PBS}$, and the leucocytes were fixed with $70 \%$ methanol. After discarding the methanol, the leucocytes were washed twice with PBS. The reduced formazan was then solubilized with $120 \mu \mathrm{l}$ of $\mathrm{KOH}$ and $140 \mu \mathrm{g}$ of DMSO, after which optical density values were read at $620 \mathrm{~nm}$ on an ELISA reader.

\section{Lysozyme activity}

Serum lysozyme activity was measured using a modified turbidimetric microtiter plate technique according to Ellis [6]. Briefly, a standard suspension of $0.15 \mathrm{mg} / \mathrm{ml}$ of Micrococcus lysodeikticus (Sigma) was prepared in $66 \mathrm{mM}$ phosphate buffer ( $\mathrm{pH}$ 6.0). Tilapia serum $(50 \mu \mathrm{l})$ was then added to $1 \mathrm{ml}$ of the bacterial suspension, after which the absorbance reduction was recorded at 0.5 and $4.5 \mathrm{~min}$ intervals at $450 \mathrm{~nm}$ on a spectrophotometer (SHIMADZU
UV-1600PC). One unit of lysozyme activity was defined as a reduction in absorbance of $0.001 / \mathrm{min}$.

\section{Phagocytic activity}

Tilapia HK leucocytes were adjusted to $1 \times 10^{6}$ cells/ $200 \mu \mathrm{l} /$ well in 5\% FBS-MEM and dispensed in an 8-well slide chamber (Nunc, Denmark), followed by overnight incubation at $25^{\circ} \mathrm{C}$. Following incubation, $1 \times 10^{7}$ cells $/ \mathrm{ml}$ of zymosan (Sigma) was added. The mixture was incubated at $25^{\circ} \mathrm{C}$ for $1 \mathrm{~h}$ with occasional shaking, after which $50 \mu \mathrm{l}$ of the mixture was smeared onto a glass slide, air-dried, and stained with Wright's solution. Phagocytic activity (PA) [26] was calculated by enumerating 500 leucocytes per fish under a microscope. $\mathrm{PA}=$ number of cells ingesting zymosans/number of cells observed $\times 100$.

\section{Statistical analysis}

Statistical significance of the differences between the groups was calculated by applying Student's 2-tailed $t$-test.

\section{Results and discussion}

Prunella vulgaris is a perennial plant known for its selfhealing properties in Western herbal medicine [27,28], and it traditionally has been used for treating various diseases such as an allergies and inflammation in East Asian countries [29]. In addition, P. vulgaris has been reported to have immunomodulatory effects such as activation of macrophages $[27,28,30]$. The effect of $P$. vulgaris on fish immunity in aquaculture has only been reported by Harikrishnan et al. [21]. Specifically, they investigated the dietary effects of $P$. vulgaris on the non-specific immune response as well as disease resistance against Uronema marinum. In the

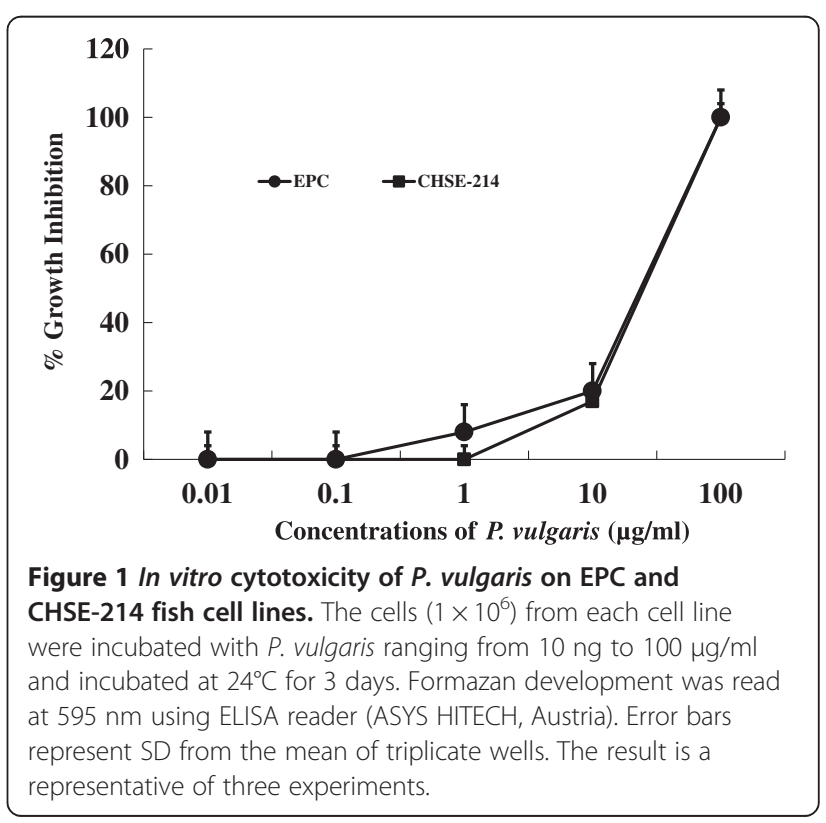


Table 1 The levels of GOT, GPT and c-creatin in tilapia sera following injection of $P$. vulgaris

\begin{tabular}{cccc}
\hline \multirow{2}{*}{$\begin{array}{c}\text { Standards } \\
\text { for } \\
\text { toxicity }\end{array}$} & PBS & P100/100 & P1000/100 \\
\cline { 2 - 4 } & $19 \pm 3 \mathrm{mg} / \mathrm{ML}$ & $23 \pm 5 \mathrm{mg} / \mathrm{ML}$ & $25 \pm 3 \mathrm{mg} / \mathrm{ML}$ \\
GOT & $40 \pm 6 \mathrm{mg} / \mathrm{ML}$ & $39 \pm 5 \mathrm{mg} / \mathrm{ML}$ & $42 \pm 6 \mathrm{mg} / \mathrm{ML}$ \\
GPT & $31 \pm 4 \mathrm{mg} / \mathrm{ML}$ & $28 \pm 5 \mathrm{mg} / \mathrm{ML}$ & $33 \pm 7 \mathrm{mg} / \mathrm{ML}$ \\
C-creatin & &
\end{tabular}

${ }^{1} \mu \mathrm{g}$ of $P$. vulgaris/g of fish.

present study, we tested the availability of $P$. vulgaris as a potent immunoadjuvant to achieve an enhanced vaccination effect. Furthermore, the in vitro and in vivo toxicities of $P$. vulgaris were investigated in tilapia as a fish model. Lastly, to determine the optimal amount of $P$. vulgaris extract that evokes an immune response in tilapia, we administered $P$. vulgaris extract by intraperitoneal (I.P.) injection.

First, we tested the in vitro and in vivo toxicities of $P$. vulgaris against transformed fish cell lines and tilapia. The half-killing concentrations of $P$. vulgaris against EPC and RTG-2 cells were 30 and $40 \mu \mathrm{g} / \mathrm{ml}$, respectively (Figure 1). These in vitro toxicities were similar to a previous study in which Korean mistletoe showed negligible toxicity on mammalian cell lines [31]. Table 1 shows the levels of GOT, GPT, and c-creatin in blood from tilapia sensitized with $P$. vulgaris. There were no significant differences in toxicity between the groups administered 100 and $1000 \mu \mathrm{g}$ of $P$. vulgaris/100 g of fish. Further, the GOT, GPT, and c-creatin levels of the PBS control group were within normal ranges, indicating non-toxicity. In contrast, a previous study showed that a 10 -fold greater concentration of mistletoe injected into eel significantly augmented toxicity [11]. The immunomodulatory effect of $P$. vulgaris was compared with those of FCA and $\beta$-glucan based on $\mathrm{HC}$-specific antibody production. As shown in Figure 2, P. vulgaris induced significantly stronger antibody production than either FCA or $\beta$-glucan. Although $\beta$-glucan failed to elicit efficient antibody production, $\beta$-glucan plus $P$. vulgaris synergistically enhanced antibody production. However, no significant difference in toxicity between the $P$. vulgaris and $P$. vulgaris plus $\beta$-glucan groups was observed, indicating that $P$. vulgaris alone has strong immunoadjuvant activity.

Phagocytes produce respiratory bursts as a form of attack against invasive pathogens. As such, they are common measure of the defense ability against pathogens, although excessive accumulation of reactive oxygen intermediates (ROIs) is extremely toxic to host cells [32]. ROIs such as superoxide $\left(\mathrm{O}_{2}{ }^{-}\right)$, hydrogen peroxide $\left(\mathrm{H}_{2} \mathrm{O}_{2}\right)$, hydroxyl radical $(\mathrm{OH})$, and singlet oxygen play important roles in the antimicrobial activity of phagocytic cells [33]. As shown in Figure 3, ROI production was significantly $(p<0.05)$ up-regulated in HK leucocytes from tilapia injected with 300 and $500 \mu \mathrm{g}$ of $P$. vulgaris/100 g of fish compared to both the control and FCA groups, suggesting that ROIs are an indicator of $P$. vulgaris-induced nonspecific immunity in tilapia. Although ROI production in the $100 \mu \mathrm{g}$ of $P$. vulgaris group was higher than that in the control group, the difference was not significant. Maximum NBT reduction value was observed in the $500 \mu \mathrm{g}$ of $P$. vulgaris group, but no significant difference was observed between the 300 and $500 \mu \mathrm{g}$ of $P$. vulgaris groups. On the other hand, injection of more than $500 \mu \mathrm{g}$ of

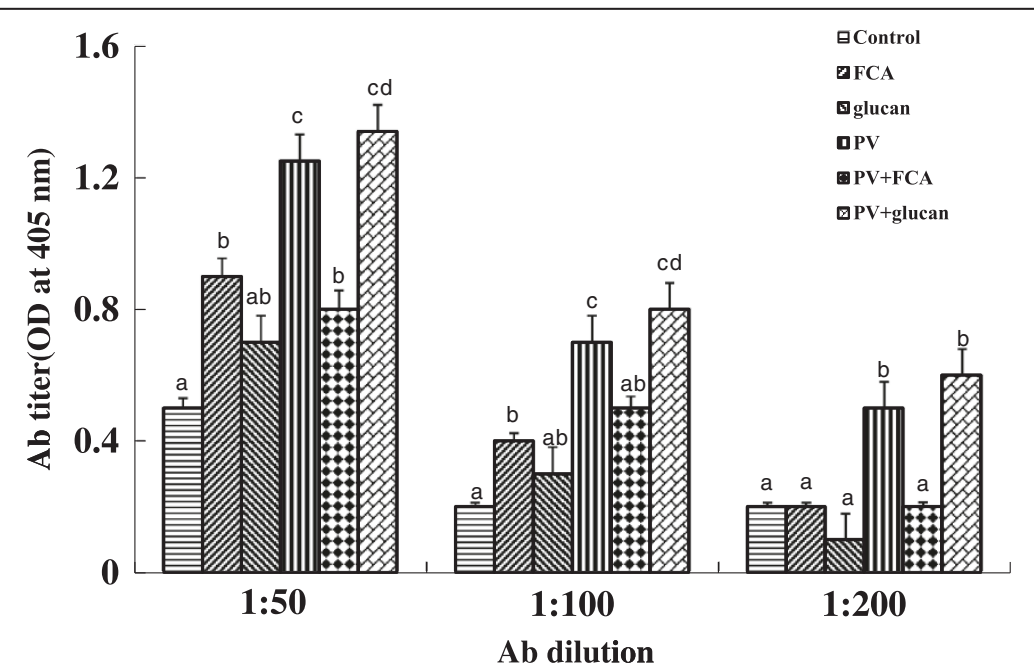

Figure 2 Antibody titer induced by $P$. vulgaris administered in tilapia. Six groups (5 fish/group) of fish were I.P. immunized with hemocyanin supplemented with P. vulgaris (PV), FCA, P. vulgaris + FCA (PV + FCA), $\beta$-glucan, P. vulgaris + $\beta$-glucan (PV + glucan) and PBS as a control, respectively. Data represent the mean + S.D. $(n=5)$. Statistical differences $(p<0.05)$ between groups are indicated by different letters over the bar. 


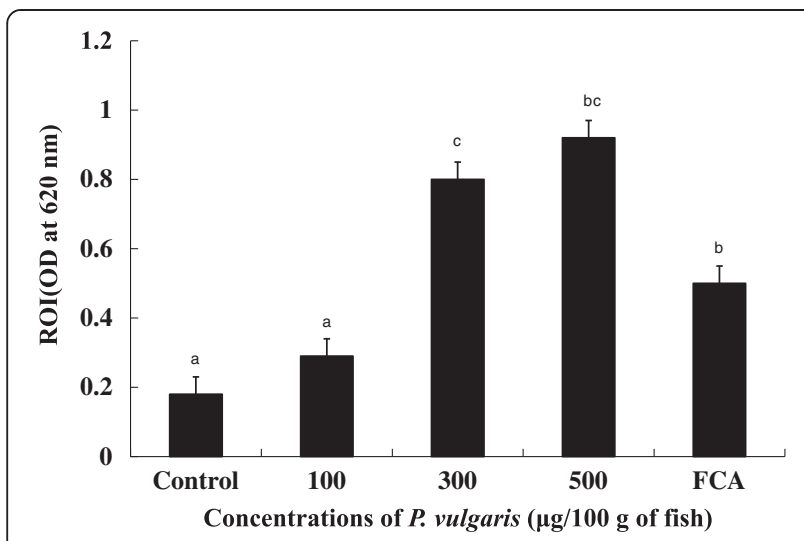

Figure 3 Respiratory burst activity of head kidney leucocytes at 4 days post-injection of $P$. vulgaris. Five groups (7 fish/group) of fish were I.P. injected with 0, 100, 300 and $500 \mu \mathrm{g} / 100 \mathrm{~g}$ of fish, and FCA. Data represent the mean + S.D. $(n=7)$. Statistical differences $(p$ $<0.05$ ) between groups are indicated by different letters over the bar.

P. vulgaris/100 g of fish failed to up-regulate ROI production (data not shown). Usually, the effect of immunostimulants is strongest at intermediate dosages with minimal activity and even toxicity at high doses [34,35]. This phenomenon has been established in fish through in vivo [36,37] and in vitro studies [38].

Lysozyme has both bactiericidal as well as opsonin effects that activate the complement system and phagocytes to prevent infection and disease [39]. Figure 4 shows lysozyme activities in the sera of tilapia with or without $P$. vulgaris administration. Serum lysozyme activities were significantly $(p<0.05)$ higher in the 300 and $500 \mu \mathrm{g}$ of $P$. vulgaris groups compared to the $100 \mu \mathrm{g}$ of $P$. vulgaris and FCA groups. Further, there was no significant difference in

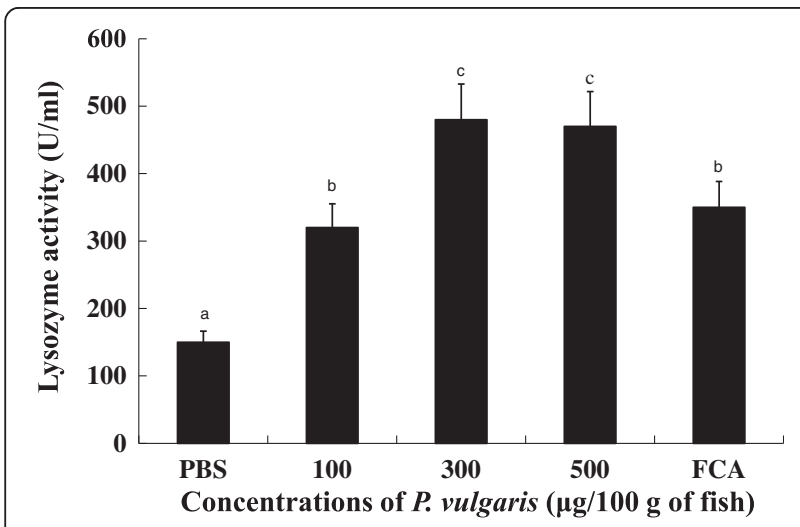

Figure 4 Lysozyme activity of tilapia head kidney leucocytes at 4 days post-injection of $P$. vulgaris. Five groups (7 fish/group) of fish were I.P. injected with 0, 100, 300 and $500 \mu \mathrm{g} / 100 \mathrm{~g}$ of fish, and FCA. Data represent the mean + S.D. $(n=7)$. Statistical differences $(p$ $<0.05$ ) between groups are indicated by different letters over the bar. lysozyme activity between the 300 and $500 \mu \mathrm{g}$ of $P$. vulgaris groups. Considering that serum from $P$. vulgarisinjected fish showed elevated lysozyme activity, $P$. vulgaris is likely to play a critical role in evoking lysozyme activity from tilapia kidney phagocytes. However, injection of $1000 \mu \mathrm{g}$ of $P$. vulgaris reduced lysozyme activity compared to the 300 and $500 \mu \mathrm{g}$ of $P$. vulgaris groups (data not shown), suggesting that an excess concentration of $P$. vulgaris interferes with lysozyme activity in tilapia.

Phagocytes are the first cells to recognize invading foreign bodies and are thus central to cell-mediated and humoral immunities [40]. To test whether or not P. vulgaris can influence phagocytic activity, tilapia kidney leucocytes sensitized with $P$. vulgaris (100, 300, and $500 \mu \mathrm{g}$ of $P$. vulgaris) were incubated overnight with zymosans. In our study, instead of foreign pathogens, zymosans were treated to phagocytes from either $P$. vulgaris-injected tilapia or nontreated tilapia. As shown in Figure 5, the phagocytic activities of HK leucocytes isolated from tilapia injected with 300 and $500 \mu \mathrm{g}$ of $P$. vulgaris were significantly higher compared to the $100 \mu \mathrm{g}$ of $P$. vulgaris and PBS control groups. Further, was a significant difference $(p<0.05)$ between the $100 \mu \mathrm{g}$ of $P$. vulgaris as well as 300 or $500 \mu \mathrm{g}$ of $P$. vulgaris groups, but no significant difference between the 300 and $500 \mu \mathrm{g}$ of $P$. vulgaris groups themselves. Lastly, excess injection of P. vulgaris $(1000 \mu \mathrm{g})$ inhibited phagocytosis and respiratory bursts in HK leucocytes isolated from tilapia.

Although the materials used in the study were different, Gopalakannan and Aurl [41] and Luo et al. [42] also reported that fish treated with a high dosage of chitosan display significantly inhibited phagocytosis compared to low dosage. This result suggests that the high level of $P$. vulgaris directly induced phagocytosis, thereby exhausting the cells.

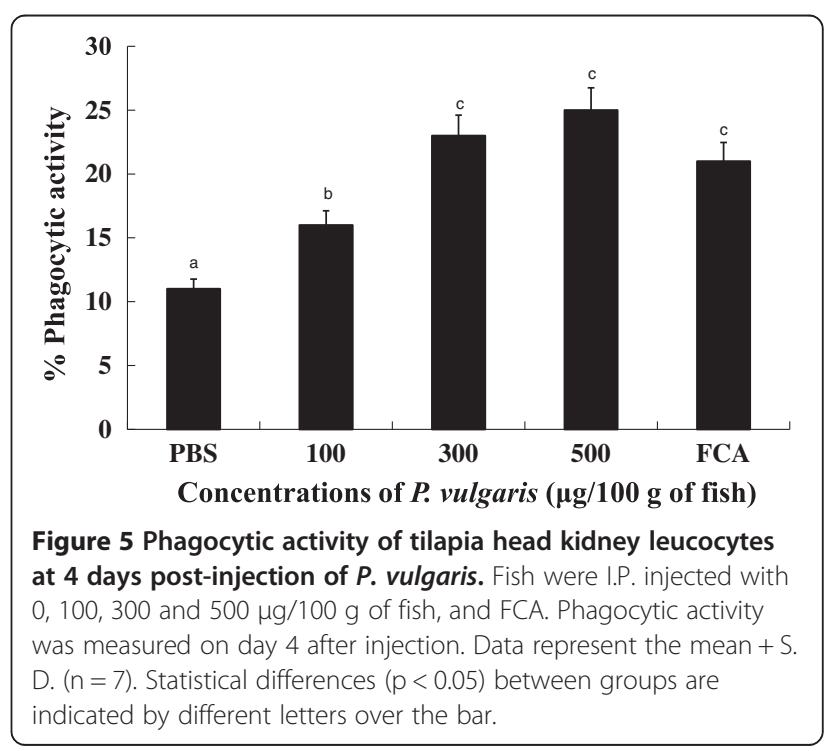




\section{Conclusions}

$P$. vulgaris elevated almost all non-specific immune parameters as well as specific humoral immunity. Therefore, $P$. vulgaris could be a promising immunomodulatory material for inducing specific and non-specific immune responses in fish. Further studies on using $P$. vulgaris as a dietary supplement in aquaculture are currently underway.

\section{Competing interests}

The authors declare that they have no competing interests.

\section{Authors' contributions}

KH collected Prunella vulgaris samples, wrote the manuscript and performed in vitro toxicity test as well as a statistical analysis. SH carried out the specific and non-specific immune-related experiments. Both authors read and approved the final manuscript.

\section{Acknowledgments}

This work was supported by a grant from the Fisheries Science Institute in Kunsan National University in 2013.

\section{Received: 7 April 2014 Accepted: 7 April 2014}

Published: 15 May 2014

\section{References}

1. Robertsen B: Modulation of the non-specific defense of fish by structurally conserved microbial polymers. Fish Shellfish Immunol 1999, 9:269-90.

2. Ai QH, Mai KS, Zhang I, Tan BP, Zhang WB, Xu W: Effects of dietary $\beta-1,3$ glucan on innate immune response of large yellow croaker, Pseudosciaena crocea. Fish Shellfish Immunol 2007, 22:394-402.

3. Selvaraj V, Sampath K, Sekar V: Administration of lipopolysaccharide increaseds specific and non-specific immune parameters and survival in carp infected with Aeromonas hydrophila. Aquaculture 2009, 286:176-183.

4. Ring $\varnothing$ E, Olsen RE, Gifstad TØ, Dalmo RA, Amlund H, Hemre Gl, Bakke AM: Prebiotics in aquaculture: a reviews. Aquacul Nutr 2010, 16:117-136.

5. Midtlyng PJ, Reitan LJ, Lillehaug A, Ramstad A: Protection, immune responses and side effects in Atlantic salmon (Salmo salar L.) vaccinated against furunculosis by different procedures. Fish Shellfish Immunol 1996, 6:599-613.

6. Ellis AE: Immunity to bacteria in fish. Fish Shellfish Immunol 1999, 9:291-308.

7. Raa J: The use of immunostimulatory substances in fish and shellfish farming. Rev Fish Sci 1996, 4:229-288.

8. Sakai M: Current research status of fish immunostimulants. Aquaculture 1999, 172:63-92

9. Peddie S, Zou J, Secombes J: Immunostimulation in the rainbow trout (Oncorhynchus mykiss) following intraperitoneal administration of Ergosan. Vet Immunol Immunopathol 2002, 86:101-113.

10. Anderson DP: Environmental factors on fish health: immunological aspects. In The fish immune system: organism, pathogen, and environment. Edited by Iwama G, Nakanishi T. San Diego, CA: Academic; 1996:289-310

11. Yoon TJ, Park KH, Choi SH: Korean mistletoe (Viscum album Coloratum) extract induces eel (Anguilla japonica) non-specific immunity. Immune Network 2008, 8(4):124-129.

12. Park KH, Choi SH: The effect of mistletoe, Viscum album coloratum, extract on innate immune response of Nile tilapia (Oreochromis niloticus). Fish Shellfish Immunol 2012, 32:1016-1021.

13. Chen D, Ainsworth AJ: Glucan administration potentiates immune defense mechanisms of channel catfish, Ictalurus punctauts Rafinesque. J Fish Dis 1992, 15:295-304.

14. Engstad R, Robertsen B, Frivold E: Yeast glucan induces increase in lysozyme and complement-mediated haemolytic activity in Atlantic salmon blood. Fish Shellfish Immunol 1992, 2:287-297.

15. Verlhac V, Gabaudan J, Obach A, Schuep W, Hole R: Influence of dietary glucan and vitamin $D$ on non-specifici responses of rainbow trout (Oncorhynchus mykiss). Aquaculture 1996, 144:123-133.

16. Castro R, Couso N, Obach A, Lamas J: Effect of different beta-glucans on the respiratory burst of turbot (Psetta maxima) and gilthead rainbow trout (Sparus aurata) phagocytes. Fish Shellfish Immunol 1999, 9:529-541.
17. Bagni M, Romano N, Finoia MG, Abelli L, Scapigliate G, Tiscar PG: Short- and long-term effects of a dietary yeast $\beta$-glucan (Macrogard) and alginic acid (Ergosan)preparation on immune response in sea bass (Dicentrarchus labrax). Fish Shellfish Immunol 2005, 18:311-325.

18. Psotova J, Kolar M, Sousek J, Svagera Z, Vicar J, Ulrichova J: Biological activities of Prunella vulgaris extract. Phytother Res 2003, 17:1082-1087.

19. Psotova J, Svobodova A, Kotarova H, Walterova D: Photoprotective properties of Prunella vulgaris and rosmariinic acid on human keratinocytes. J Photochem Photobiol B 2006, 84:167-174.

20. Oh C, Price J, Brindley MA, Widrlechner MP, Qu L, McCoy JA, Murphy P, Hauck D, Maury W: Inhibition of HIV-1 infection by aqueous extracts of Prunella vulgaris L. Virol J 2011, 23:8-12.

21. Harikrishnan R, Kim JS, Kim MC, Balasundaram C, Heo MS: Prunella vulgaris enhances the non-specific immune response and disease resistance of Paralichthys olivaceus against Uronema marinum. Aquaculture 2011, 318:61-66.

22. Lee JB, Kang TB, Choi SH, Lee U, Kim AJ, Jeong CJ, Lee HC, Cho YS, Won JG, Lim JC, Yoon TJ: Effect of Prunella vulgaris Labiatae extract on inmate immune cells and anti-metastatic effect in mice. Food Sci Biotechnol 2009, 18(1):218-222

23. Daly JG, Moore AR, Olivier G: A colorimetric assay for the quantivication of brook trout (Salvelinus fontinalis) lymphocyte mitogenesis. Fish Shellfish Immunol 1995, 5:265-273.

24. Santarem M, Novoa B, Figueras A: Effect of beta-glucans on the nonspecific immune responses of turbot (Scophthalmus L.). Fish Shellfish Immunol 1997, 7:429-437.

25. Secombes $\mathrm{CJ}$, Chung S, Jeffries AH: Superoxide anion production by rainbow trout macrophages detected by the reduction of ferricytochrome C. Dev Comp Immunol 1988, 12:201-206

26. Sahoo PK, Mukherjee SC: Effect of dietary $\beta-1,3$ glulcan on immune responses and disease resistance of healthy and aflatoxin B1-induced immunocompromised rohu (Labeo rohita Hamilton). Fish Shellfish Immunol 2001, 11:683-695.

27. Fang X, Chang RC, Yuen WH, Zee SY: Immune modulatory effects of Prunella vulgaris L. Int J Mol Med 2005, 15:491-496.

28. Fang X, Yu MM, Yuen WH, Xee SY, Chang RC: Immune modulatory effects of Prunella vulgaris L. on monocytes/macrophages. Int J Mol Med 2005, 16:1109-1116

29. Kim SY, Kim SH, Shin HY, Lim JP, Chae BS, Park JS, Hong SG, Kim MS, Jo DG, Park WH, Shin TY: Effects of Prunella vulgaris on mast cell-mediated allergic reaction and inflammatory cytokine production. Exp Biol Med 2007, 232:921-926.

30. Han EH, Choi JH, Hwang YP, Park HJ, Choi CY, Chung YC, Seo JK, Jeong HG: Immunostimulatory activity of aqueous extract isolated from Prunella vulgaris. Food Chem Toxicol 2009, 47(1):62-69.

31. Yoon TJ, Yoo YC, Kang TB, Her E, Kim K, Azuma I, Kim JB: Cellular and humoral adjuvant activity of lectins isolated from Korean mistletoe (Viscum album colaratum). Int Immunopharmacol 2001, 1:881-889.

32. Salinas I, Cuesta A, Esteban MA, Meseguer J: Dietary administration of Lactobacillus delbrueckii and Bacillus subtilis, single or combined, on gilthead seabream cellular innate immune responses. Fish Shellfish Immunol 2005, 19:67-77.

33. Babior BM: Oxidants from phagocytes: agents of defense and destruction. Bolld 1984, 64:959-966.

34. Bliznakov EG, Adler AD: Nonlinear response of the reticuloendothelial system upon stimulation. Pathol Microbiol 1972, 38:393-410.

35. Gialdroni-Grassi G, Grassi C: Bacterial products as immunomodulating agents. Int Arch Allergy Appl Immunol 1985, 76(Supp.1):119-127.

36. Kenyon CJ, MCKeever A, Oliver JA, Henderson IW: Control of renal and adrenocortical function by the renin-angiotensin system in two euryhaline teleost fishes. Gen Comp Endocrinol 1985, 58:93-100.

37. Anderson DP, Jeney G: Immunostimulants added to injected Aeromonas salmonicida bacterin enhance the defense mechanisms and protection on rainbow trout (Oncorhynchus mykiss). Vet Immunol Immunopathol 1992, 34:379-389.

38. Siwicki AK, Cossarini-Dunier M, Studnicka M, Demael A: In vivo effect of the organophosphorus insecticide trichlorphon on immune response of carp (Cyprinus carpio). II. Effect of high doses of trichlorphon on nonspecific immune response. Ecotoxicol Environ Saf 1990, 19:99-105.

39. Alexander JB, Ingram GA: Noncellular non-specific defense mechanisms of fish. Ann Rev Fish Dis 1992, 2:249-79. 
40. Cavaillon JM: Cytokines and macrophages. Biomed Pharmacother 1994, 48:445-453.

41. Gopalakannan A, Aurl V: Immunomodulatory effects of dietary intake of chitin, chitosan and levamisole on the immune system of Cyprinus carpio and control of Aeromonas hydrophila infection in ponds. Aquaculture 2006, 255:179-187.

42. Luo L, Cai X, He C, Xue M, Wu X, Cao H: Immune response, stress resistance and bacterial challenge in juvenile rainbow trouts Oncorhynchus mykiss fed diets containing chitosan-oligosaccharides. Curr Zool 2009, 55:416-22.

doi:10.1186/2055-0391-56-3

Cite this article as: Park and Choi: Effects of Prunella vulgaris labiatae extract on specific and non-specific immune responses in tilapia (Oreochromis niloticus). Journal of Animal Science and Technology 2014 56:3.

\section{Submit your next manuscript to BioMed Central and take full advantage of:}

- Convenient online submission

- Thorough peer review

- No space constraints or color figure charges

- Immediate publication on acceptance

- Inclusion in PubMed, CAS, Scopus and Google Scholar

- Research which is freely available for redistribution 